\title{
PELATIHAN PENYUSUNAN PROFIL WISATA BERBASIS TEKNOLOGI INFORMASI DI DESA SUDAJI, KABUPATEN BULELENG
}

\author{
Ni Made Ary Widiastini ${ }^{1)}$, Nyoman Dini Andiani ${ }^{2}$, Putu Indah Rahmawati ${ }^{3)}$, \\ I Wayan Putra Yasa ${ }^{4}$, Gede Wirata ${ }^{5}$ \\ 1), 2), 3)Fakultas Ekonomi, Universitas Pendidikan Ganesha, ${ }^{4}$ Fakultas Hukum dan Ilmu Sosial, \\ Universitas Pendidikan Ganesha, ${ }^{5}$ Fakultas Ilmu Sosial dan Ilmu Politik, Universitas Ngurah \\ Rai, Universitas Pendidikan Ganesha, \\ e-mail: ${ }^{1)}$ ary.widiastini@gmail.com ${ }^{2)}$ demeilovedini@gmail.com ${ }^{3)}$ putuindah@yahoo.co.id \\ 4)yanputra666@gmail.com ${ }^{5)}$ wirata_gede@yahoo.com
}

\begin{abstract}
Abstrak
Tersedianya informasi yang berbasis teknologi saat ini merupakan tuntutan bagi berbagai pelaku usaha pariwisata, termasuk desa wisata. Dalam hal ini informasi pariwisata yang baik, terpercaya dan terbaharukan sangat dibutuhkan agar sebuah destinasi wisata mampu diketahui dan dikenal dengan baik, khususnya bagi wisatawan. Profil desa wisata yang merupakan gambaran menyeluruh tentang karakter desa dan jenis kepariwisataan yang dikembangkan di suatu desa sangat penting untuk disusun dan diketahui oleh pihak masyarakat yang terlibat di dalam pengembangan desanya sebagai desa wisata, serta dipublikasikan kepada pihak yang akan berkontribusi positif terhadap pengembangan pariwisata di desa tersebut. Desa Sudaji yang telah mengembangkan dirinya sebagai desa wisata, belum memiliki data profil desa wisata yang dibutuhkan untuk menginventarisasi data desanya, baik sumber daya manusia, sumber daya alam, sumber daya budaya, prasarana pariwisata, dan sarana pariwisata. Data tersebut sangat penting untuk tahap pengembangan selanjutnya, agar kegiatan pariwisata dapat dilakukan secara bertahap, terkoordinasi dan berkelanjutan. Pada kegiatan pengabdian ini, penyusunan profil desa wisata yang dilakukan secara manual, dimasukkan ke dalam sistem teknologi dengan tujuan untuk mempermudah akses informasi oleh pihak yang membutuhkan data untuk pembangunan dan pengembangan desa, khususnya Desa Sudaji. Diharapkan dengan tersedianya profil desa wisata di Desa Sudaji secara lengkap, valid dan selalu terbaharui dapat berguna untuk kemajuan desa wisata yang dikembangkan di desa tersebut.
\end{abstract}

Kata Kunci: Pariwisata, Pedesaan, Profil, Desa Sudaji

\section{PENDAHULUAN}

Pariwisata pedesaan merupakan tren kepariwisataan yang berkembang saat ini, dimana tujuannya adalah memberikan kontribusi optimal bagi masyarakat di dalam pengembangan pariwisata. Perencanaan dan pelaksanaan pengembangan pariwisata pedesaan baik oleh pemerintah yang dibantu oleh akademisi, investor maupun masyarakat itu sendiri seringkali mengalami berbagai masalah, yang diakibatkan tidak tersedianya data sumber daya manusia, sumber daya alam, sumber daya budaya yang tersedia di desa tersebut. Bahkan program-program yang diberikan oleh pihak luar dalam bentuk pengabdian pun seringkali terjadi tumpang tindih, dimana jenis program yang diberikan adalah sama, yang seharusnya dapat diberikan 
adalah keberlanjutan program. Hal ini terjadi karena tidak terdatanya sumber daya dan kegiatan kepariwisataan yang disusun secara sistematis, valid dan senantinya dilakukan pembaharuan data secara berkala.

Informasi sebagaimana dalam pandangan Davis (1999) merupakan data yang telah mengalami pengolahan sehingga menjadi sebuah bentuk baru yang dapat dengan mudah dipahami oleh pihak yang diharapkan sebagai penerima informasi. Praktiknya, data dapat berupa sebuah catatan yang dinarasikan sesuai kebutuhan dari pihak yang menjadi target penerima informasi, sehingga dapat berguna bagi pihak-pihak tersbeut, khususnya dalam membuat sebuah keputusan (Wahyono, 2004; Jogiyanto, 2005).

Tersedianya data desa yang lengkap, valid dan up to date merupakan hal yang penting di dalam pengembangan suatu desa menjadi desa wisata, mengingat kompleksnya masalah yang dihadapi, serta tersebarnya data akan mampu menjadi hambatan di dalam pengembangan pariwisata pedesaan yang berbasis potensi desa. Salah satu desa yang sedang mengembangkan dirinya sebagai desa wisata adalah Desa Sudaji. Desa Sudaji, Kecamatan Sawan memiliki beragam potensi wisata yang dapat dikembangkan secara berkesinambungan untuk menjadi tempat wisata percontohan. Daya tarik wisata yang telah dikembangkan oleh Desa Sudaji diantaranya trecking, wisata spiritual, agrowisata, pentas seni budaya, dan yang terbaru adalah berupa arung jeram. Selain itu, dimilikinya tradisi Bukakak yang jatuhnya bertepatan dengan waktu kunjungan wisatawan terbanyak yakni high season (pada bulan Juni hingga bulan Juli), menjadikan desa ini sangat potensial untuk mengembangkan desanya sebagai pariwisata pedesaan yang juga memanfaatkan potensi budaya sebagai salah satu atraksi wisatanya. Desa Sudaji memiliki atraksi wisata berupa pertanian dan akses yang unik untuk menuju air terjun di Desa Sekumpul dan Desa Lemukih. Aktivitas pawisata yang selama ini dilaksanakan di Desa Sudaji, Sekumpul dan Lemukih selalu berupaya melibatkan masyarakat, hal ini bisa dilihat dengan adanya pemanfaatan aktivitas masyarakat dalam pawisata. Seperti yang dilakukan di Desa Sudaji dan Lemukih dengan adanya daya tarik berupa pemandangan sawah dan juga aktivitas bertani masyarakat menjadi salah satu produk unggulan yang dikembangkan selain daya tarik utama lainnya.

Selain potensi aktivitas pertanian terdapat berbagai aktivitas lainnya yang bisa dikemas dalam kontek mewujudkan desa wisata antara lain aktivitas religius masyarakat seperti piodalan di setiap pura di ketiga desa ini. Kemudian ada juga aktivitas daur hidup orang Bali dari upakara kelahiran sampai pada kematian. Jika itu dikemas dijadikan sebagai kemasan pariwisata berbasis masyarakat dengan konsep the riil Balinese life tentunya sangat menarik dan bisa memberikan pengalaman yang berbeda pada tamu yang datang ke desa ini. Kemudian untuk memberikan alternatif bagi kebutuhan wisatawan yang berkunjung yang memiliki minat yang berbeda bisa dikembangkan objek wisata pendukung seperti objek foto selfi, trekking, cycling, water slide, dan sebagainya. Keberadaan objek tentunya itu bisa menjadi pendukung potensi wisata yang sudah ada seperti air terjun di Desa Sekumpul dan Lemukih. Keberadaan aktivitas wisata pendukung tersebut menjadi alternatif bagi wisatawan untuk menikmati kegiatan wisata yang berbeda sesuai dengan daya tarik yang dimilikinya. Di samping untuk menikmati objek wisata utama berupa air terjun dan aktivitas perkebunan.

Berdasarkan hasil wawancara dengan pengelola objek wisata Lemukih dan Sekumpul, kunjungan wisatawan di 
dua objek ini cukup ramai terutama pada musim liburan jumlah berkisar dari puluhan orang sampai pada ratusan orang perharinya. Wisatawan yang datang umumnya adalah wisatawan luar negeri dan wisatan lokal maupun nasional. Wisatawan yang berkunjung ke air terjun tersebut sebagian besar didatangkan dari Desa Sudaji, sehingga pencatatan jumlah kunjungan wisatawan haruslah berbeda untuk di Desa Sudaji dan tempat atraksi wisata tersebut. Data tentang kunjungan wisatawan haruslah dilakukan dengan baik, mengingat hal tersebut juga akan menjadi dasar pertimbangan bagi pemerintah di dalam pengembangan desa wisata. Kedatangan wisatawan ke air terjun yang didatangkan dari Desa Sudaji selama ini seringkali tercatat hanya di tempat atraksi, sehingga hal tersebut akan menjadi permasalahan di kemudian hari, seperti kontribusi terhadap aspek ekonomi. Namun, sebagaimana persyaratan umum dalam pengembangan suatu daerah menjadi tempat tujuan wisata haruslah memiliki dan menyediakan atraksi yang menarik, fasilitas pariwisata yang sesuai dengan kebutuhan wisatawan, akses yang memadai serta kelembagaan pariwisata yang sesuai dengan kebutuhan bentuk pariwisata yang dikembangkan. Keberadaan empat persyaratan tersebut haruslah terdata dengan sebelum dilakukan pengembangan desa wisata, sehingga memudahkan pembuatan perencanaan bentuk pariwisata. Oleh sebab itu, tersedinya profil desa wisata merupakan hal yang akan sangat membantu Desa Sudaji di dalam pengembangan daerahnya sebagai desa wisata yang memiliki keunikan tersendiri.

\section{METODE KEGIATAN}

Kegiatan pengabdian kepada masyarakat yang dilakukan selama enam bulan di Desa Sudaji dengan melibatkan kelompok sadar wisata Gandameru, dua mahasiswa perhotelan dan satu orang yang memahami pembuatan teknologi informasi, profil wisata Desa Sudaji disusun dan dimasukkan ke dalam sistem sudajitourism.com.

Memahami bahwa di dalam memasukkan data agar menjadi informasi yang mudah dipahami oleh pihak sasaran, maka dalam kegiatan ini membutuhkan ahli bidang teknologi informasi agar data yang ditampilkan pada sistem informasi yang dimaksud dapat bermanfaat bagi pihak sasaran, dan berimplikasi positip bagi pengembangan pariwisata di Desa Sudaji. Dengan demikian, solusi yang ditawarkan pada kegiatan ini serta metodenya dilakukan dengan tahapan yakni :

1. Melakukan kerjasama dengan pihak yang memiliki kemampuan di bidang teknologi dan informasi, yang juga memahami kondisi Desa Sudaji.

2. Menentukan domain dan hosting.

3. Mengumpulkan data dengan melibatkan pihak-pihak yang bertugas di dalam pengumpulan data.

4. Menyeleksi data yang akan dimasukkan ke dalam sistem data base profil wisata Desa Sudaji.

5. Merancang desain sistem informasi.

6. Melatih masyarakat memasukkan data ke menu

7. Melatih masyarakat melakukan update data

8. Melaksanakan pendampingan jarah jauh dengan menggunakan media sosial dalam membantu pihak yang dipilih sebagai tim data untuk melakukan update data atau menambah data baru.

\section{HASIL YANG DICAPAI DAN PEMBAHASAN}

\subsection{Penyediaan Profil Wisata Desa Sudaji Melalui Sudajitourism.com}

Kegiatan pengabdian masyarakat ini diawali dengan pemikiran bahwa 
potensi yang dimiliki oleh Desa Sudaji tidak terdata dengan baik, sehingga menyulitkan pembuatan program pengembangan pariwisata. Dibantuk oleh salah satu masyarakat di Desa Sudaji yang memiliki kemampuan terkait sistem teknologi informasi, kegiatan pengabdian ini dapat dilaksanakan dengan baik. Melalui Pastika, domain sudajitourism.com pun dibuat dengan dasar pertimbangan memunculkan nama Desa Sudaji sebagai destinasi wisata. Nama sudajitourism.com digunakan sebagai nama untuk memperkenalkan potensi Desa Sudaji baik dari unsur demografi, geografi, dan potensi wisatanya kepada khalayak umum.

Kolaborasi antara teknologi dan pariwisata penting dilakukan. Sebab teknologi informasi yang sudah menjadi kebutuhan setiap kehidupan manusia, praktiknya harus diadopsi baik secara individu maupun lembaga/organisasi, begitu pula dengan desa yang mengembangkan dirinya sebagai desa wisata. Ibrahim (2009); Ria PZ, dkk (2014); Yuliandari, dkk (2017); Putra, dkk (2018); dan Herawati, dkk (2018) menjelaskan bahwa teknologi informasi adalah salah satu faktor penting yang berfungsi untuk mendukung dan mempromosikan potensi-potensi yang dimiliki oleh desa yang mengembangkan dirinya sebagai desa wisata, dan melalui teknologi informasi yang baik, pengelola desa wisata mampu melakukan kolaborasi dengan pihak terkait, khususnya yang membidani kepariwisataan. Herawati, dkk (2018: 225) menjelaskan bahwa teknologi informasi saat ini menjadi salah satu faktor penting dalam mendukung dan mempromosikan potensi wisata suatu daerah. Dengan kombinasi yang sinergis dari sektor pariwisata dan teknologi informasi, informasi tentang potensi wisata suatu daerah dapat disampaikan kepada wisatawan tanpa batas waktu dan ruang. Berkaitan dengan masalah ini, ecommerce adalah salah satu manifestasi dari penggunaan teknologi internet, yang telah populer dan berkembang, untuk pertukaran informasi. Selain itu, Yuliandari, dkk (2017: 145) menegaskan bahwa sistem informasi merupakan kombinasi dari manusia, teknologi, media, prosedur dan pengendalian, termasuk menata jaringan komunikasi yang penting, proses terkait transaksi-transaksi, serta membantu manajemen dan pemakai dari pihak internal maupun eksternal di dalam pengambilan keputusan. Dengan demikian, sudajitourism.com yang menampilkan unsur profil desa dan wisata yang terdapat di Desa Sudaji, tidak saja bermanfaat dalam konteks mempromosikan aktivitas wisata kepada wisatawan, tetapi juga pada pihak lain seperti dinas pariwisata, akademisi, maupun pihak terkait yang memiliki keinginan untuk memberikan sebuah program kegiatan pengabdian kepada masyarakat bagi Desa Sudaji.

Nama sudajitourism.com dipilih dengan dasar pertimbangan tetap menampilkan nama desa yang dikembangkan ke arah wisata. Sebagaimana Riyanto (2015:34) menyarankan bawah website sebagai salah satu bentuk respon untuk memenuhi kebutuhan pelanggan dalam hal kepercayaan harus memerhatikan lima hal yakni (1) memiliki domain ".co.id" atau ".com"; (2) menggunakan nama brand yang akan diperkenalkan; (3) mencantumkan alamat perusahaan; dan (4) mencantumkan nomor telepon perusahaan yang aktif. Dengan demikian, pada sudajitourism.com, nama sudaji digunakan sebagai alasan bahwa yang ingin diperkenalkan adalah nama desa itu sendiri, yakni Desa Sudaji. Begitu pula di dalam sudajitourism.com, nama pengelola desa wisata, nama pemilik homestay, nama guide, berikut juga nonor telepon yang dapat dihubungi diinput ke dalam sistem. Sudajitourism.com, ke depannya diharapkan mampu menjadi pemasaran Desa Sudaji sebagai desa wisata dengan 
sistem satu pintu. Dalam hal ini, meskipun banyak penginapan di desa tersebut yang membuat web sebagai sarana promosi pribadi, tetapi, diharapkan datanya pun masuk ke sudajitourism.com, yang nantinya akan mempermudah pihak pengguna di dalam mengakses informasi terkait desa tersebut.

\subsection{Penyusunan Halaman Depan Sudajitourism.com}

Informasi sebuah produk di era digital harus diberikan dengan baik, yang bertujuan untuk memberikan kepercayaan bagi masyarakat pengguna informasi, sehingga produk yang ditampilkan dapat diterima secara rasional oleh sasaran, serta dipilih sebagai produk yang wajib dibeli. Bahkan, pada era tampilan, atau era tampak depan, pemilik produk harus mampu menampilkan produknya dengan baik dan menarik, sesuai dengan pihak yang diinginkan sebagai target atau sasaran produk. Sudajitourism.com dipilih dengan tujuan untuk memperkenalkan nama Desa Sudaji sesuai dengan potensinya, baik pada aspek geografi, demografi dan hal-hal yang berkaitan dengan kepariwisataan. Sebagaimana Dewi dan Wicaksana (2008: 562), menegaskan bahwa fungsi utama promosi adalah agar semakin banyak peselancar internet mengunjungi website yang dipromosikan, sehingga aspek penting dari promosi website adalah tampilannya website pada indeks mesin pencari (serach engine) ketika pengguna internet melakukan pencarian (searching). Selain itu, Dewi dan Wicaksana (2008: 563) juga menegaskan agar kata kunci yang digunakan dalam website harus berhubungan dengan isi yang ada dalam halaman-halaman web. Website (Yuliandari, dkk, 2017: 145), adalah suatu halawan web yang saling berhubungan yang umumnya berada peladen yang sama berisikan kumpulan informasi yang disediakan secara perorangan, kelompok, atau organisasi.

Informasi tentang destinasi, sebagaimana gagasan Ria Pz, dkk (2014: 277) menjelaskan bahwa merancang sebuah paket wisata ke dalam situs web harus memerhatikan berbagai faktor. Situs web yang mempromosikan situs wisata di wilayah tujuan, baik situs web pribadi (seperti blog yang membagikan pengalaman kunjungan wisata) maupun situs web pemerintah dapat dikategorikan sebagai situs web yang hanya memberikan informasi statis. Informasi statis yang tersedia di situs web belum mampu membantu pengunjung (calon wisatawan) untuk mencari informasi yang lebih lengkap ketika mereka ingin melakukan perjalanan ke lokasi wisata. Informasi "bagaimana" mencapai situs wisata tidak tersedia di sebagian besar situs web. Oleh sebab itu, kebutuhan pasar yakni pengguna internet yang menjadi target sasaran dari situs web yang dibuat, harus dianalisis dengan baik, sehingga data yang ditampilkan sesuai dengan kebutuhan pasar, yakni wisatawan atau pihak terkait kepariwisataan.

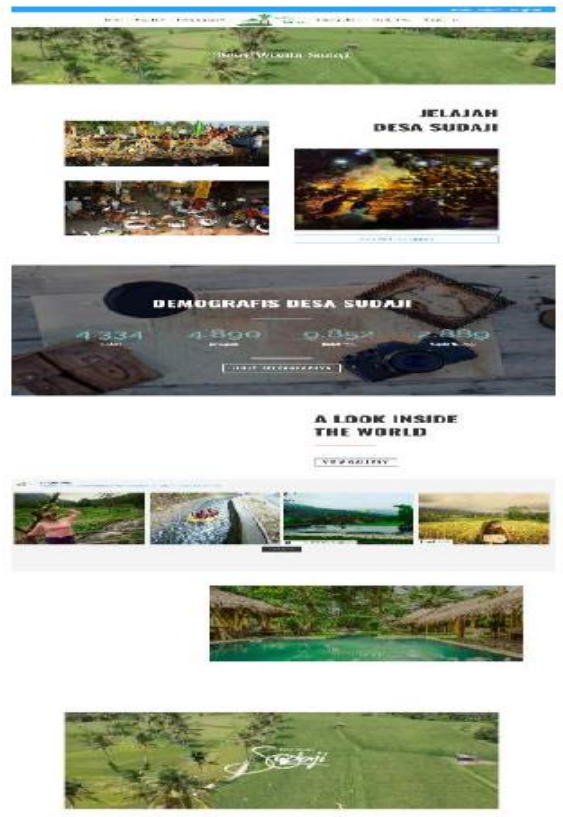

Gambar 1: Tampilan Depan Sudajitourism.com 
Tampilan atau tampak permukaan, atau yang sering disebut sebagai first sight secara langsung, diakui maupun tidak, telah mampu membentuk sebuah citra. Sebagaimana gagasan Setiadi dalam Sondakh (2014: 23), citra sebuah produk, baik yang bersifat tangible maupun intangible, merupakan representasi dari keseluruhan persepsi terhadap merek dan bentuk dari informasi dan pengalaman masa lalu terhadap merek itu. Praktiknya, konsumen yang memiliki citra positip terhadap sebuah produk akan memungkinkan mereka untuk memilih dan/atau membeli. Begitu juga dengan informasi di website, dengan tampilan yang meyakinkan akan mampu menggiring konsumen untuk melanjutkan penjelajahannya tentang Desa Sudaji, setelah dalam dirinya setuju dan tertarik untuk meneruskan pencarian data selanjutnya, yang dipengaruhi oleh tampilan pada halaman depan website.

\subsection{Menu-Menu}

Pada

\section{Sudajitourism.com}

Informasi yang dimuat pada sudajitourism.com adalah tentang profil wisata Desa Sudaji, dalam hal ini yang menjadi menu dalam website tersebut adalah profil tentang desa yang menyangkut aspek geografi, administrasi, demografi, dan unsur pariwisata. Unsur pariwisata yang dimaksud adalah potensi alam, potensi budaya, kegiatan wisata buatan, kegiatan wisata alam, kegiatan wisata budaya, akomodasi, transportasi, dan pemandu wisata yang merupakan anggota dari kelompok sadar wisata Gandameru. Sebagaimana Ria PZ (2014: 282) menjelaskan bahwa sistem informasi online harus dirancang untuk dapat membantu calon wisatawan dalam membuat perencanaan pariwisatanya. Dalam hal ini, sistem dijalankan sesuai dengan aturan fungsional dan bisnis yang dirancang dan mampu menampilkan informasi yang sesuai dengan yang diberikan oleh pengguna. Maka, sesuai dengan fungsinya, sudajitourism.com pun dibuat dengan menampilkan data kelengkapan desa, dimana tujuan penggunanya bukanlah hanya pada wisatawan, melainkan juga pihak lain yang memiliki program pengabdian kepada masyarakat yang akan dilaksanakan di Desa Sudaji, sebagai salah satu desa wisata yang sedang diarahkan menjadi desa wisata yang berkelanjutan di Kabupaten Buleleng.

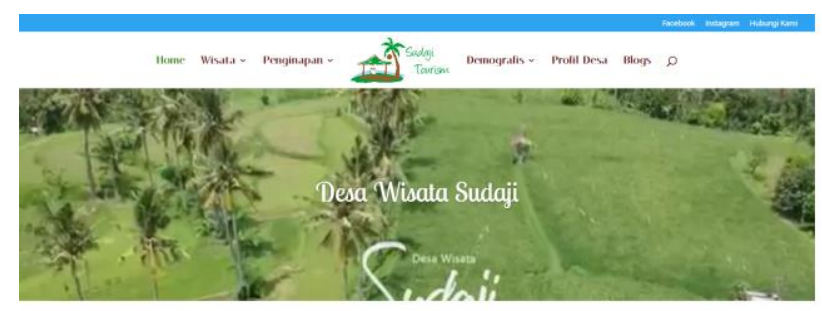

Gambar 2 : Menu sudajitourism.com

Menu yang tampil pada sudajitourism.com terdiri dari atas informasi wisata, informasi, informasi tentang kemasyarakatan atau demografi, sejarah dan pemandu wisata yang akan membantu wisatawan selama berkunjung ke Desa Sudaji.

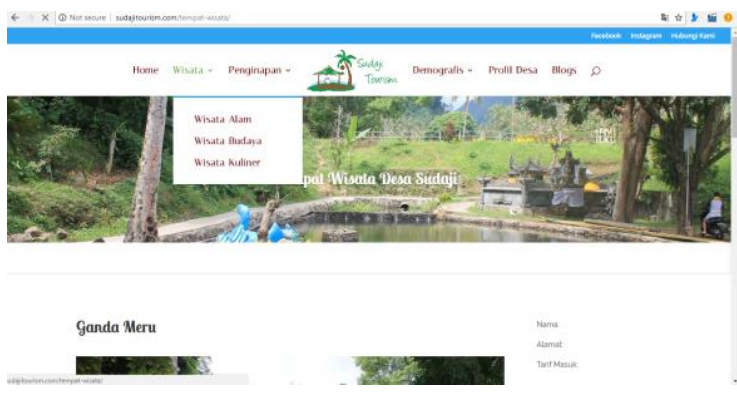

Gambar 3: Menu Wisata sudajitourism.com Informasi tentang wisata yang ditampilkan pada sudajitourism.com dibagi atas informasi wisata alam, wisata budaya dan wisata buatan/ man made attraction. Pada menu ini dijelaskan tentang potensi dan kegiatan wisata yang dapat dilakukan oleh wisatawan ketika berkunjung ke Desa Sudaji. 


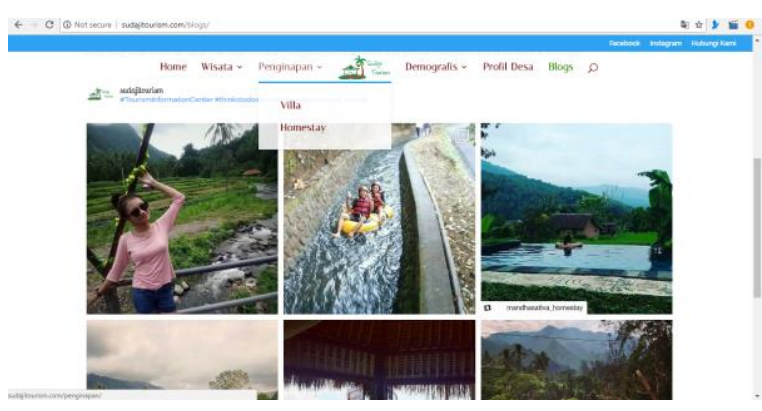

Gambar 4 : Menu Akomodasi sudajitourism.com

Pada menu penginapan dijelaskan tentang jumlah penginapan yang tersedia di Desa Sudaji, jumlah kamar, pihak yang bisa dihubungi serta harga kamar yang dijual per malan kepada wisatawan yang menginap.
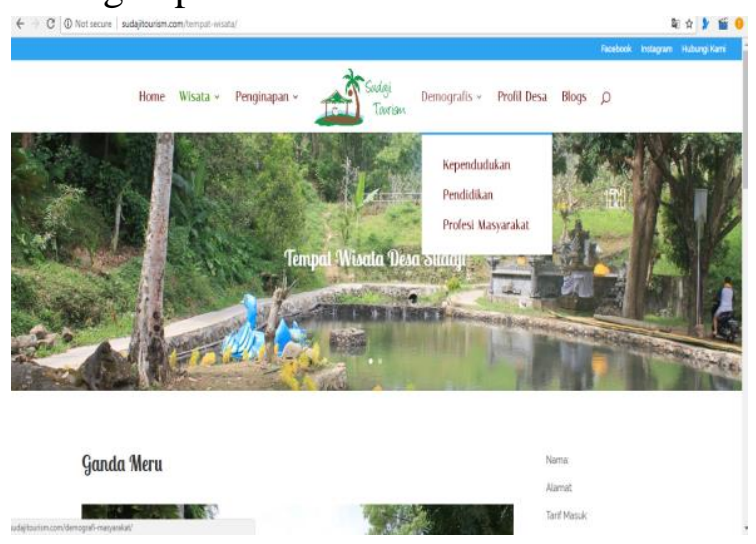

Gambar 5 : Menu Demografi sudajitourism.com Pada menu demografi dijelaskan tentang jumlah masyarakat berdasarkan jenis kelamin, jenis pekerjaan dan pendidikan masyarakat. Dalam hal ini sumber daya manusia yang tersedia di Desa Sudaji terdata pada sudajitourism.com.

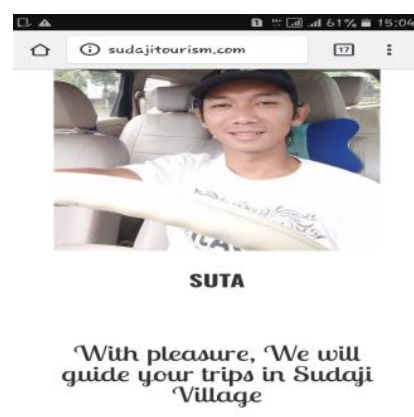

Gambar 6: Menu Guide sudajitourism.com Pada sudajitourism.com juga ditampilkan identitas pemandu wisata lokal yang berisikan foto dan nomor yang bisa dihubungi. Pemandu lokal tersebut merupakan anggota dari Kelompok Sadar Wisata Gandameru, Desa Sudaji.

\subsection{Pelatihan Input Data Pada Menu Sudajitourism.com}

Penyusunan profil wisata Desa Sudaji berbasis teknologi informasi, dalam prakriknya melibatkan tiga pihak, yakni (1) akademisi sebagai insiator program, mengumpulkan data, memilah data; (2) ahli TI yang membantu pembuatan website dan hal -hal yang akan dimasukkan ke data di website tersebut; dan (3) masyarakat yang tergabung dalam kelompok sadar wisata Gandameru yang bertugas membantu mengumpulkan data dan diberikan pelatihan oleh ahli TI untuk mampu menjadi admin pada website tersebut. Penyusunan profil wisata Desa Sudaji berbasis TI ini memiliki dua sasaran penting yakni konsumen (wisatawan) dan pihak pemilik program CRS atau pengabdian kepada masyarakat (dinas terkait, BUMN, kementerian terkait dan akademisi). Interaksi sistem dalam aplikasi arsitektur, mengutip gagasan Preece dalam Herawati (2018: 234), dapat dilihat bentuk interaksinya.

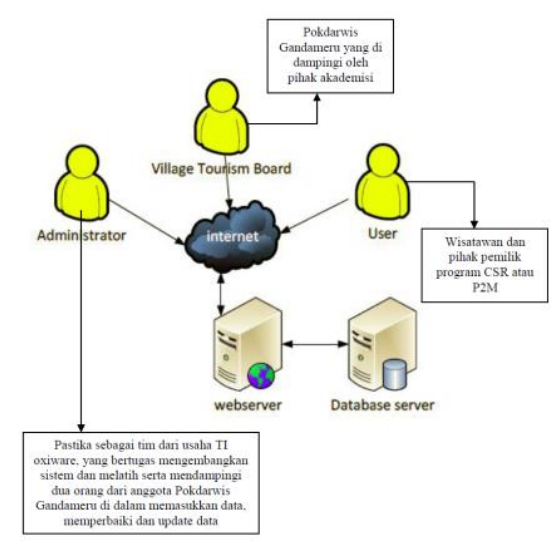

Gambar 7: Pihak yang terlibat dalam penyusunan profil wisata Desa Sudaji

Dalam penyusunan profil wisata Desa Sudaji, ketua pelaksana kegiatan pengabdian kepada masyarakat 
melibatkan dosen dengan berbagai disiplin ilmu, ahli TI yang memahami teknik pembuatan website dan hal-hal yang terkait dalam pembuatan data base di sudajitourism.com, dan masyarakat yang merupakan anggota kelompok sadar wisata Gandameru yang cukup memahami teknologi informasi yang nantinya akan menjadi admin dibawah pengawasan ketua pelaksana, mahasiswa Perhotelan Undiksha dan pihak TI. Dengan demikian, kegiatan ini tidak selesai dalam waktu singkat, tetapi akan terus berproses seiring data terbaru yang diperoleh di lapangan. Pendampingan akan berakhir apabila, admin dari Pokdarwis Gandameru telah mampu melakukan update data dan mengelola data secara mandiri.

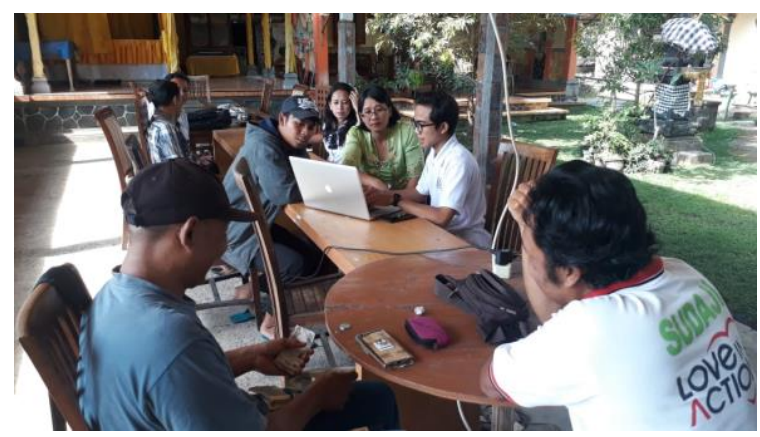

Gambar 8 : Kegiatan Pelatihan di Rumah Ketua Pokdarwis

Menyadari bahwa masyarakat terdiri atas dua tipe yakni mereka tahu potensi namun tidak memahami pengelolaan atau pemanfaatannya, dan mereka yang sama sekali tidak tahu potensi yang dimiliki serta tidak memahami pengelolaannya, maka pendekatan yang diterapkan dalam program pengabdian kepada masyarakat pun harus berbeda, disesuaikan dengan kondisi masyarakat mitra. Sebagaimana gagasana Adi (2012: 166-167), pendekatan masyarakat dapat dilakukan dengan dua cara yakni pendekatan direktif (instruktif) dan pendekatan nondirektif (partisipatif). Pendekatan direktif dilakukan berlandasrkan asumsi bahwa community worker tahu apa yang dibutuhkan dan apa yang baik untuk masyarakat. Dalam pendekatan ini, peranan community worker bersifat lebih dominan karena prakarsa kegiatan dan sumber daya yang dibutuhkan lebih banyak berasal dari community worker. Dalam hal ini community worker lah yang menetapkan apa yang baik atau buruk bagi masyarakat, cara -cara apa yang perlu dilakukan untuk memperbaikinya dan selanjutnya menyediakan sarana yang diperlukan untuk perbaikan tersebut. Dengan pendekatan seperti ini, prakarsa dan pengambilan keputusan berada di tangan community worker. Sedangkan, pendekatan nondirektif (partisipatif) dilakukan berlandaskan asumsi bahwa masyarakat tahu apa yang sebenarnya mereka butuhkan dan apa yang baik untuk mereka. Pada pendekatan ini, community worker pemeran utama dalam perubahan masyarakat adalah masyarakat itu sendiri, community worker lebih bersifat menggali dan mengembangkan potensi masyarakat. Masyarakat diberikan kesempatan untuk membuat analisis dan mengambil keputusan yang berguna bagi mereka sendiri untuk tujuan yang mereka inginkan. Pada kondisi di Desa Sudaji, pendekatan yang dilakukan adalah pendekatan non direktif, karena masyarakat sudah memahami kebutuhan mereka, namun memerlukan pendampingan.

\subsection{Pendampingan Lanjutan Melalui Media Sosial}

Pelaksanaan program pengabdian masyarakat di Desa Sudaji dengan mengambil tema kegiatan berupa penyusunan profil wisata Desa Sudaji tentu tidak bisa dilakukan dalam waktu yang relatif singkat. Dalam hal ini, proses input data ke dalam sistem yakni pada sudajitourism.com memerlukan data yang cukup banyak, validasi data oleh pihak yang berwenang yakni masyarakat desa itu sendiri, serta melakukan pembaharuan data seiring dengan meningkatkan jumlah penginapan, bertambahnya kegiatan 
wisata, meningkatkan jumlah kunjungan wisatawan, bergantinya nomor telepon pemandu lokal, dan hal-hal lain yang harus diperbaharui di website tersebut. Dalam hal ini, data akan terus dimasukkan ke sudajitourism.com secara periodik, sehingga di dalam pelaksanaannya tetap memerlukan pendampingan. Namun, tidak tersedianya dana dalam melakukan pendampingan lanjutan secara langsung yakni bertemu di Desa Sudaji, maka pendampingan dapat dilakukan dengan menggunakan media sosial berupa email, sms, telepon dan WA. Kemudahan teknologi informasi yang tersedia saat ini tidak menjadi penghalang bagi kelanjutan pendampingan bagi kelompok sadar wisata di Desa Sudaji untuk menyempurnakan website desanya menjadi sarana informasi satu pintu yang dapat diakses oleh banyak orang, namun terorganisir secara melembaga yakni oleh Pokdarwis Gandameru.

Teknik pendampingan jarak jauh dengan menggunakan media sosial yang telah dipilih dan disepakati bersama, diharapkan mampu menjadi solusi belajar anggota Pokdarwis Gandameru yang dipilih sebagai admin pada sudajitourism.com. Pendampingan yang diberikan oleh pihak akademisi sebagai pelaksana kegiatan pengabdian kepada masyarakat, dan pihak TI, mengadopsi proses pembelajaran dengan sistem emoderating. Salmon (2005), menjelaskan tentang E-Moderating yakni "The Key to Teaching and Learning Online". Sebagaimana dalam gagasan Salmon (2005), E-moderator dibutuhkan untuk membawa pengalaman belajar ke kehidupan, yang baginya pendidikan dan pelatihan online adalah kegiatan yang bermanfaat. Dalam hal ini ditekankan olehnya bahwa peserta didik membutuhkan tujuan dan struktur dasar yang harus diberikan oleh e-moderator. Praktiknya, pembelajaran dengan sistem e-moderating dibantu komputer dan komputer-mediated conferencing atau yang dikenal dengan istilah $\mathrm{CMC}$ (Computer-mediated Conferencing). Salmon (2005) juga menjelaskan lima level dalam e-moderating, dimana hal penting yang harus dipahami oleh seorang peserta CMC untuk menguasai keterampilan teknis tertentu, begitupula emoderator diharapkan untuk mendukung peserta di setiap tahap.

- Tahap 1: akses dan motivasi. Pada ini, level terendah, pekerjaan e-moderator adalah untuk menyambut dan mendorong peserta. Pada titik ini, peserta harus mengatur komputernya sedemikian rupa sehingga ia dapat mengakses sistem.

- Tahap 2: Sosialisasikan Online. Peserta mulai secara mandiri mengirim dan membaca pesan. E-moderator mendukung peserta dengan membangun jembatan antara berbagai elemen.

- Tahap 3: Pertukaran informasi. Para peserta saling bertukar informasi dengan semakin banyak peserta lain, emoderator harus berhati-hati bahwa pada titik ini ia mengarahkan diskusi ke jalur-jalur sedemikian rupa sehingga ia sendiri dapat menjawab semua pertanyaan yang muncul.

- Level 4: Membangun Pengetahuan. Para peserta mendapatkan lebih banyak dan lebih banyak wawasan dari diskusi yang semakin terbuka satu sama lain dan, pada gilirannya, menyajikannya. E-moderator memiliki tugas untuk meringkas keadaan saat ini dari waktu ke waktu, untuk menunjukkan hubungan antara titik diskusi dan - jika minat dalam topik saat ini reda - untuk memulai topik baru.

- Tahap 5: Pengembangan. Pada tahap ini, pembelajar sendiri bertanggung jawab untuk apakah dan bagaimana mereka mengimplementasikan peluang yang dimediasi komputer. Pada tahap ini, peserta didik mulai berpikir kritis tentang sistem dan memberikan saran untuk perbaikan. 
Melalui e-moderating, pemberi pengetahuan atau pendamping dan yang diberi pengetahuan atau yang di damping, dapat melakukan komunikasi dengan mudah memlaui fasilitas internet secra regular, waktu fleksibel/ kapan saja, tanpa ada batas jarak, tempat dan waktu, bergantung atas kesepakatan dan kesepakatan bersama. E-moderating (Samlon, 2000) adalah proses melibatkan peserta didik dalam diskusi, awalnya memfasilitasi diskusi dan kemudian mengambil langkah untuk memungkinkan siswa untuk mendorong diskusi yang sedang berlangsung dan membangun pengetahuan baru. Elemen penting dari emoderating adalah peran fasilitator online yang dikenal sebagai e-moderator. Peran e-moderator adalah salah satu aspek terpenting dari proses pembelajaran. Dalam hal ini pelaksana pengabdian bekerjasama dengan ahli TI beperan sebagai e-moderator, yang membantu anggota Pokdarwis Sudaji yang dipilih sebagai admin untuk bisa menambahkan data ke menu pada sudajitourism.com, melakukan updating data, hingga bisa mengelola web tersebut secara mandiri.

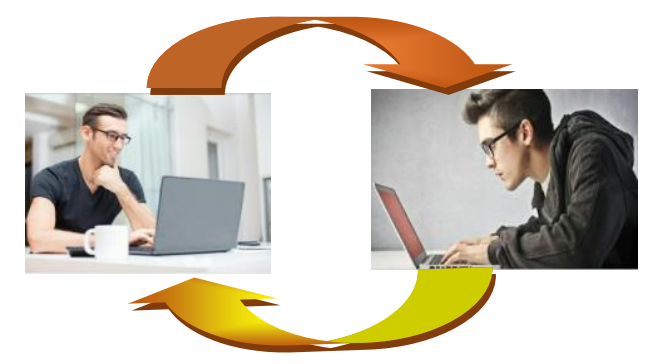

Gambar 9. Ilustrasi interaksi antara pendamping dan yang di damping

Pendampingan bagi masyarakat Desa Sudaji dengan menggunakan model belajar e-moderating, sebagaimana (Gilly, 2000), menjelaskan terdapat dua motif bagi kelompok orang untuk bekerja bersama. Salah satunya adalah kepentingan pribadi dan kepentingan umum lainnya. Faktor ekstrinsik, seperti insentif, tetapi yang kedua membutuhkan kepercayaan dan saling menghormati. Jadi dari awal e-moderator harus mencari iklim peningkatan yang kuat dari kesejahteraan kelompok online, berdasarkan rasa hormat dan dukungan untuk satu sama lain daripada pemotongan sudut dalam pelayanan tujuan pribadi instrumental. Dengan cara ini, motivator intrinsik akan didorong untuk muncul dan belajar.

\section{SIMPULAN DAN SARAN Simpulan}

Program pengabdian kepada masyarakat sebagai sebuah program rutin yang dilaksanakan oleh lembaga pendidikan sangat bermanfaat bagi masyarakat, akademisi maupun pemerintah. Pada kesempatan ini program pengabdian kepada masyarakat yang dilaksanakan pada kelompok masyarakat yakni Kelompok Sadar Wisata Gandameru, Desa Sudaji dengan memberikan pelatihan berupa penyusunan data desa dan data wisata ke dalam sebuah sistem teknologi informasi yakni sudajitourism.com.

\section{Saran}

Program serupa tidak hanya berhenti pada program ini saja, karena masyarakat merasa masih perlu pendampingan yang lebih lanjut, serta mendapatkan ide ide yang bagus guna perkembangan wisata di desanya. Pokdarwis diharapkan juga terus memperhatikan keberlanjutan pengelolaan website dengan selalu memperbaharui berita di beranda situs yang telah disediakan. Selain itu, pihak desa juga perlu mengadakan sosialisasi berkaitan dengan program pengembangan desa sehubungan dengan pengembangan pariwisata dan membangkitkan kesadaran masyarakat utama bagi kaum muda untuk mau membangun desanya. 
DIFUSI

Volume 1, N0. 2, Juli 2018

\section{DAFTAR PUSTAKA}

Davis, Gordon B. 1999. Kerangka Dasar Sistem Informasi Manajemen. PT. Pustaka Binaman Pressindo, Jakarta

Herawati, Anita. Anna Purwaningsing. Yonathan Dri Handharko. 2018. Promoting Village Tourism Through the Development of Information Systems. Review of Integrative Business and Economics Research, Vol 7, Supplementary Issue 1, Pg 221-236

Ibrahim, Ali. 2009. Developing a We-Bases System of Bengkulu Tourist. Jurnal Sistem Informasi (JSI), Vol.1, No.3, Desember 2009. Hal 128140

Jogiyanto, H.M.2005. Analisis dan Desain Sistem Informasi. ANDI: Yogyakarta.

Putra, Fajar Kusnadi Kusumah. Pudin Saepudin. Edwin Adriansyah. I Gusti Agung Wahyu Adtian. 2018. Digital Tourism : A Content Analysis of West Java Tourism Websites. Journal of Indoensian Tourism and Development Studies. Vol.6, No. 2, Pg 7384.

Ria PZ, Rosleini. Adhie Tri Wahyudi. Bagus Ismail AW. 2014. Designing Package Travel in Ex-Surakarta Region with Semantic Trip Planning. ICETIA. ISSN 2407-4330, pg $277-$ 277-282.

Riyanto, Andi Dwi. 2015. Pembuatan Website Sebagai Media Promosi Yang Terpercaya. Seminar Nasional Informatika UPN Veteran Yogyakarta, 14 Nopember 2015

Salmon, G. (2005). E-moderating: The key to teaching and learning online. United Kingdom: Kogan Page.

Wahyono, Teguh. 2004. Sistem Informasi Konsep Dasar, Analisis, Desain dan Implementasi. Penerbit : Graha Ilmu, Yogyakarta.

Yuliandari, Dewi. Oryza Gilang. Feri Prasetyo. 2017. Rancang bangun Sistem Informasi Pariwisata Kecamatan Muaragembong Berbasis Web. Jurnal Sisfokom, Volume 06, Nomor 02, Septemer 2017. Halaman 144-151 